\section{HEALTH AND FITNESS MANAGEMENT THROUGH YOGA}

Syed Kareemulla Professor cum Director of Physical Education, Dravidian University, Kuppam, Andhra Pradesh, India

\subsection{6/bjsm.2010.078725.236}

Introduction Modern technology is trying hard to make our life easier. Now throughout the world man appears to be living a more and physically inactive life, he rides instead of walks, sits instead of standing and watches instead of participation. Thus there is an urgent need to bring about positive changes in the present day life-styles by participating in yoga, sports and physical education programmes.

Health 'A state of complete Physical, Mental and Social well being and not merely the absence of disease or infirmity'.

Physical fitness 'Physical fitness is the ability to carry out ones own routine activity without fatigue'.

Yoga Yoga originated in India. The word yoga is derived from the Sanskrit root 'YUJ' meaning to find the 'Yoke' our ancient sages have suggested eight stages of yoga to secure purity of body, mind and soul and final communion with God.

The various stages of yoga classified into (1) Yama (social discipline), (2) Niyama (individual discipline), (3) Asana (postures), (4) Pranayama (breath control), (5) Pratyahara (discipline of the senses), (6) Dharana (concentration), (7) Dhyana (meditation) and (8) Smadhi (self-realisation).

Need of yoga Yoga is quite effective and easy to do these not only exercise the limbs and the trunk, but also the visceral vital organs, improving their disease resistance capacity. In fact, yoga is the medicine of the body which can restore the vigour of the vital organs like the heart and kidneys, etc.

\section{Importance of physical fitness}

- efficiency in work and performance

- develop immunity power resistance to disease

- efficient functioning of various systems of body

- proper development of body

- mental health of alertness

- ageing processes and longevity

- success in games and sports.

\section{Dimensions of health}

- physical well-being
- mental and emotional well-being

- social well-being

- spiritual well-being.

Development and maintenance of fitness and health

- regularity (daily yogic practices)

- progression

- total body involvement

- tolerance

- rest, sleep and recreation

- good habits

- proper nutrition

- medical check-up

40 Min yoga for health and fitness

Yogasanas $5 \mathrm{~min}$

Pranayama $4 \mathrm{~min}$

Concentration $\quad 5 \mathrm{~min}$

Meditation $\quad 5 \mathrm{~min}$

Surya namaskara $\quad 5 \mathrm{~min}$

Bandhas and Mudras $5 \mathrm{~min}$

Shat Kriyas $6 \mathrm{~min}$

Relaxation (Shavasana) $5 \mathrm{~min}$

Conclusion The first wealth is health. Health and fitness - a way of life. The healthy and fit citizen assets to the nation and ill-health citizen debt to the nation. The health and fitness is not only for us but also for our coming generation. 